\title{
Effect of Previous Calcium Hydroxide Dressing on the Sealing Properties of the New Endodontic Cement Apical Barrier
}

\author{
Maryam Bidara \\ Reza Disfania \\ Salman Gharagozlob \\ Armita Rouhania \\ Maryam Forghania
}

\section{ABSTRACT}

Objectives: Using the fluid filtration method, an in vitro study was conducted to evaluate the effects of medication with calcium hydroxide on the sealing ability of the New Endodontic Cement (NEC) apical barrier in the short and long terms.

Methods: Fifty extracted single rooted teeth were prepared and apical resorption produced using acid sulfuric for four days. The teeth were randomly divided into two experimental groups $(n=20)$ and two control groups. In group 1, calcium hydroxide was placed into all canals for one week and in group 2, no medication was used. In both groups, a $4 \mathrm{~mm} \mathrm{NEC} \mathrm{apical} \mathrm{plug} \mathrm{was} \mathrm{placed} \mathrm{in} \mathrm{the} \mathrm{canals}$ and the remaining portion of the canals was filled with gutta-percha. The amount of microleakage of all samples was evaluated after one week and three months. The data were statistically analyzed using two-way ANOVA.

Results: There was no significant difference between the two groups in either time period ( $P>$.05). In both group 1 and group 2, microleakage increased after three months but this increase was not statistically significant $(P>$.05).

Conclusions: According to the result of this study, medication with calcium hydroxide had no adverse effect on the short- and long-term sealing properties of an NEC apical plug. (Eur J Dent 2011;5:260-264)

Key words: Calcium hydroxide; Apical barrier; Leakage; Fluid filtration; New Endodontic Cement.

a Department of Endodontics, Dental Research Center of Mashhad University of Medical Sciences, Mashhad, Iran.

b Endodontist, Private Practice, Mashhad, Iran.

- Corresponding author: Dr. Maryam Forghani, Dental Research Center of Mashhad University of Medical Sciences, Mashhad, Iran

Phone: +985118829501 Fax: +985118829500

E-mail: forghanirad_mayahoo.com

\section{INTRODUCTION}

Adequate endodontic therapy in an immature tooth with a necrotic pulp has many problems. The lack of an apical stop or apical constriction makes it difficult both to achieve complete debridement and to limit the filling process to within the root canal space. ${ }^{1}$ In addition to immature teeth, overfilling (iatrogenic causes) and root end resorption can lead to distraction of apical constriction. 
The most common treatment method traditionally used for teeth with open apices has been cleaning and filling the canal with a temporary paste to induce the formation of calcified tissue at the apex. The term apexification is used to describe this procedure. ${ }^{2} \mathrm{Ca}(\mathrm{OH})_{2}$ alone or in combination with other drugs is the most widely accepted material to promote apexification. ${ }^{3}$

The creation of physiologic hard tissue barrier using calcium hydroxide has several disadvantages. The treatment requires multiple appointments and takes anywhere from 3 to 18 months. ${ }^{1}$ Additional negative factors are susceptibility to fracture, ${ }^{4}$ coronal microleakage and esthetic demands during the long term treatment. ${ }^{5}$

Placement of artificial hard tissue barrier with a variety of materials has been suggested as an alternative to traditional apexification..$^{6-10}$ The material widely employed as apical barrier is MTA. MTA's popularity as an apical barrier can be attributed to several factors. It is biocompatible, ${ }^{11-13}$ can be placed in as little as one visit, ${ }^{14}$ can induce hard tissue formation ${ }^{13,15}$ and has good sealing properties. ${ }^{16,17}$

Despite these advantages, MTA has poor handling characteristics ${ }^{18}$ and a long setting time. ${ }^{19}$

A New Endodontic Cement (NEC) consisting of different calcium compounds (e.g., calcium oxide, calcium phosphate, calcium carbonate, calcium silicate, calcium sulfate, calcium hydroxide and calcium chloride) has recently been developed whose clinical applications are similar to those of MTA. NEC and MTA have similar physical properties include working time, $\mathrm{PH}$, and dimensional changes. ${ }^{20}$ They also have similar antimicrobial activity. ${ }^{21}$ NEC has good handling characteristics ${ }^{22}$ and is able to produce hydroxyapatite. ${ }^{23}$ In an ex vivo study, NEC exhibited similar sealing properties to MTA when used as root-end filling material. ${ }^{24}$ Asgary et al ${ }^{25}$ found that MTA and NEC have similar favorable biologic responses in pulp cap treatment. Since the vast majority of teeth with nonvital pulps are infected, one or two visits of calcium hydroxide therapy are performed in order to disinfect the root canal system. ${ }^{1}$ Kenee et $\mathrm{al}^{26}$ assessed the efficacy of various calcium hydroxide removal techniques and found that no technique removed all $\mathrm{Ca}(\mathrm{OH})_{2}$.

Due to the inability of complete removal of calcium hydroxide from dentinal walls, it is necessary to perform research on the effects of the calcium hydroxide remnants on the sealing ability of the apical barrier. The purpose of this study was to evaluate the effects of calcium hydroxide on the seal of the NEC apical barrier in the short and long terms.

\section{MATERIALS AND METHODS}

Fifty extracted human maxillary single-root teeth were selected for this ex vivo experimental study. All procedures were carried out according to protocols approved by the Ethics Committee of Shaheed Beheshti University of medical sciences, Tehran, Iran in 2005. The teeth were placed in $5.25 \%$ sodium hypochlorite for five hours to remove debris. The teeth were radiographed to examine for fracture, and internal and external resorption. Clinical crowns were removed with a high-speed diamond saw (D \& Z Germany) under copious water spray to create a standardized root length of about $14 \mathrm{~mm}$.

The canals were prepared with K-files (Dentsply Maillefer, Tulsa, Switzerland) and Gates- Glidden drills \# 1-4 (Dentsply Maillefer, Tulsa, OK) using the crown-down technique. Then the access opening was sealed with Coltozol (Coltene, Altstatten, Switzerland). The method of Ghoddusi et al. was used to develop apical resorption. ${ }^{27}$ The roots were submerged in melted rose wax up to 3 $\mathrm{mm}$ from the anatomic apex and then the waxed teeth were soaked in $20 \%$ sulfuric acid. After four days the teeth were rinsed with a saline solution and the wax was removed with a scalpel (Supa, Tehran, Iran). The temporary filling was also removed from the coronal access.

Then, the teeth were randomly divided into two experimental groups $(n=20)$ and two control groups ( $n=5)$. In group $1(n=20)$, calcium hydroxide was placed in each canal using a lentulo spiral (Moyco Union Brach, York, PA) and a radiograph was taken to ensure complete coverage of the canal. The teeth were stored at $100 \%$ humidity and $37^{\circ} \mathrm{C}$ for seven days. Following this stage the calcium hydroxide was removed with stainless steel hand files (Dentsply Maillefer, Tulsa, Switzerland) and $0.5 \% \mathrm{NaOCL}$ irrigation. In group 2 ( $n=20$ ), nothing was placed into the canals prior NEC use.

All teeth were then mounted in putty blocks to simulated clinical situation. The NEC was mixed with its liquid to provide a dense creamy mixture 
and was placed with a messing gun and a hand plugger at the apical end of the root. The material was condensed with the tip of hand plugger for achievement of the plug. All apical plugs of the experimental groups had the same thickness ( $4 \mathrm{~mm}$ ). Next, using a size $40 \mathrm{~K}$-file with a rubber stop positioned $4 \mathrm{~mm}$ shorter than the root canal length, the excess material was removed for fabrication of 4-mm-thick apical plugs. Radiographs were taken to ensure the proper placement and thickness of the NEC plug. Then moistened paper point was used to remove the excess NEC from the dentinal walls and teeth were stored at $100 \%$ humidity and $37^{\circ} \mathrm{C}$. After seven days, the NEC plug was tested to ensure an adequate set with a kfile and the remaining portion of the canals was obturated with thermoplasticized gutta-percha without a sealer. The coronal seal was achieved by 2-3 mm thickness of Coltozol (Coltene, Altstatten, Switzerland).

In the positive control group the teeth were not filled at all. In the negative control group $(n=5)$, the teeth were filled as in group 2, then all root surfaces and the apical barriers were covered with two layers of nail varnish. After one week and three months all samples were connected to a fluid filtration system and the amount of microleakage was evaluated.

The data were statistically analyzed using twoway ANOVA test. The significance level was defined as $\alpha=0.05$.

\section{RESULTS}

The negative controls showed no evidence of bubble movement, whereas all positive controls showed immediate transportation of the air bubble.

Table 1 shows mean microleakage data in $\mu \mathrm{l}$ $\mathrm{min} / \mathrm{cmH}_{2} \mathrm{O}$. Analysis of the results in both evaluation periods (one week and three months), showed no significant differences between group 1 lwith calcium hydroxide medication) and group 2 (without calcium hydroxide medication) (P>.05). In both groups, microleakage increased after three months but this increase was not statistically significant $(P>$.05).

\section{DISCUSSION}

Several methods that have been used to make open apex teeth include overfilling with large files $^{28}$ or the retrograde application of NiTi rotary files. ${ }^{29}$ The disadvantage of these methods is that they create round apical foramen that may not resemble the natural resorption.

In this study, the Ghoddusi et al ${ }^{27}$ method was used to make open apex teeth. In this method, 20\% sulfuric acid resorbes root surface irregularity in a manner that may be like the clinical situation.

In a nonvital immature tooth, the canal is often wider apically than coronally and mechanical instrumentation of all dentinal walls is difficult. In addition to this problem, thin roots might make mechanical instrumentation undesirable because it might further weaken the root or result in perforation. Thus before the placement of an apical barrier in open apex teeth, it has been recommended that the canals be medicated with calcium hydroxide for at least one week. The rationale is to disinfect the root canal system and ensure periapical healing. ${ }^{1}$

Sjogren et $\mathrm{al}^{30}$ found that calcium hydroxide for one week was highly effective in killing root canal flora. Hasselgren et al ${ }^{31}$ showed that calcium hydroxide can be effective in dissolving necrotic pulp tissue.

However, the complete removal of calcium hydroxide from dentinal walls in these teeth is difficult. In this study, we used light instrumentation and copious irrigation using $0.5 \% \mathrm{NaOCL}$ for removal of calcium hydroxide. A lower strength of sodium hypochlorite was used because of the danger of extruding $\mathrm{NaOCl}$ through the open apex in a clinical situation. ${ }^{1}$

Several methods have been used to measure leakage around filling materials, such as dye penetration, light microscopic methods, and SEM. The most important disadvantage of these methods is that they can only reveal the presence or absence

Table 1. The mean microleakage of four groups in two periods of time $\left(\mu \mathrm{L} / \mathrm{min} / \mathrm{cm} \mathrm{H}_{2} \mathrm{O}\right)$.

\begin{tabular}{|c|c|c|c|c|c|}
\hline \multirow[b]{2}{*}{ Sub groups } & \multirow[b]{2}{*}{ Number } & \multicolumn{2}{|c|}{7 days after obturation } & \multicolumn{2}{|c|}{3 months after obturation } \\
\hline & & Mean & Std. Deviation & Mean & Std. Deviation \\
\hline G1 & 20 & 0.0554 & 0.0069 & 0.0558 & 0.0092 \\
\hline G2 & 20 & 0.0562 & 0.0104 & 0.0576 & 0.012 \\
\hline
\end{tabular}


of leakage, but not the amount. ${ }^{32}$ Fluid filtration microleakage test is supposed to be a better alternative than dye leakage tests. ${ }^{33}$ Therefore, the fluid filtration method has been used to measure the leakage of apical plugs in this study.

Hachmeister et al ${ }^{29}$ found that one-week of calcium hydroxide therapy had no adverse effect on the sealing ability of MTA in 70 days. They concluded that the remnants of calcium hydroxide along the root walls in an open apex tooth do not affect the properties of MTA. Porkaew et $\mathrm{al}^{34}$ who investigated the effects of calcium hydroxide remnants on the sealing ability of gutta-percha and sealer, found a significant decrease in dye leakage in canals that medicated with calcium hydroxide.

\section{CONCLUSIONS}

No previous study has evaluated the effect of calcium hydroxide remnants on the seal of the NEC apical plug. According to the results of this study, medication with calcium hydroxide had no adverse effect on the short- and long-term sealing properties of NEC as an apical plug. Further studies focused on the long-term success rate of the NEC apical plug are warranted before it can be recommended for clinical application.

\section{ACKNOWLEDGMENT}

This study was supported by the Dental Research Center of Mashhad University of Medical Sciences. The authors wish to thank Dr. H. Esmaili for his advice as a statistician in this study.

\section{REFERENCES}

1. Martin Trope. Endodontic considerations in dental trauma: Endodontics. Hamilton, BC Deker Inc, 2008:1337.

2. Steiner JC, Dow PR, Cathey GM. Inducing root end closure of nonvital permanent teeth. J Dent Child 1968;35:47-54.

3. Camp JH, Fuks AB. Pediateric endodontics: endodontic treatment for the primary and young permanent dentition: Pathways of the pulp. Mosby, St. Louis 2006:871.

4. Andreasen JO, Farik B, Munksgaard EC. Long-term calcium hydroxide as a root canal dressing may increase risk of root fracture. Dent Traumatol 2002;18:134-137.

5. Holden DT, Schwartz SA, Kirkpatrick TC, Schindler WG. Clinical outcomes of artificial root-end barriers with mineral trioxide aggregate in teeth with immature Apices. $J$ Endod 2008;34:812-817.
6. Tronstad L. Tissue reactions following apical plugging of the root canal with dentin chips in monkey teeth subjected to pulpectomy. Oral Surg Oral Med Oral Pathol 1978;45:297304.

7. Brandell DW, Torabinejad M, Bakland LK, Lessard GM. Demineralized dentin, hydroxyapatite and dentin chips as apical plug. Endod Dent Traumatol 1986;2:210-214.

8. Rossmeisl R, Reader A, Melfi R, Marquard J. A study of freeze-dried (lypophilized) dentin used as an apical barrier in adult monkey teeth. Oral Surg Oral Med Oral Pathol 1982;53:303-310.

9. Schumacher JW, Rutledge RE. An alternative to apexification. J Endod 1993;19:529-531.

10. Torabinejad M, Chivian N. Clinical applications of mineral trioxide aggregate. J Endod 1999;25:197-205.

11. Keiser K, Johnson CC, Tipton DA. Cytotoxicity of mineral trioxide aggregate using human periodontal ligament fibroblasts. J Endod 2000;26:288-291.

12. Torabinejad M, ford TR, Abedi HR, Kariyawasam SP, Tang HM. Tissue reaction to implanted root-end filling materials in the tibia and mandible of guinea pigs. $J$ Endod 1998;24:468-471.

13. Osorio RM, Hefti A, Vertucci FJ, Shawley AL. Cytotoxicity of endodontic materials. J Endod 1998;24:91-96.

14. Steinig TH, Regan JD, Gutmann JL. The use and predictable placement of mineral trioxide aggregate in one visit apexification cases. Aust Endod J 2003;29:34-42.

15. Apaydin E, Shabahang S, Torabinejad M. Hard-tissue healing after application of fresh or set MTA as root-end-filling material. J Endod 2004;30:21-24.

16. Shabahang S, Torabinejad M, Boyne PP, Abedi H, McMillan P. A comparative study of root-end induction using osteogenic protein-1, calcium hydroxide and mineral trioxide aggregate in dogs. J Endod 1999;25:1-5.

17. AL-Hezaimi K, Naghshbandi J, Oglesby S, Simon JH, Rotestein I. Human saliva penetration of root canals obturated with two types of mineral trioxide aggregate cements. $J$ Endod 2005;31:453-456.

18. Chng HK, Islam I, Yap AU, Tong YW, Koh ET. Properties of a new root-end filling material. J Endod 2005;31:665-668.

19. Torabinejad M, Hong CU, McDonald F, Pitt Ford TR. Physical and chemical properties of a new root-end filling material. J Endod 1995;21:349-353.

20. Asgary S, Shahabi S, Jafarzadeh T, Amini S, Kheirieh S. The properties of a new endodontic material. $J$ Endod 2008;34:990-993.

21. Hasan Zarrabi M, Javidi M, Naderinasab M, Gharechahi M. Comparative evaluation of antimicrobial activity of three cements:new endodontic cement (NEC), mineral trioxide aggregate (MTA) and Portland. J Oral Sci 2009;51:437-442. 
22. Asgary S, Eghbal MJ, Parirokh M. Sealing ability of a novel endodontic cement as a root-end filling material. J Biomed Mater Res A 2008;87:706-709.

23. Asgary S, Eghbal MJ, Parirokh M, Ghoddusi J. Effect of two storage solutions on surface topography of two root-end fillings. Aust Endod J 2009;35:147-152.

24. Asgary S, Eghbal MJ, Parirokh M, Torabzadeh H. Sealing ability of three commercial mineral trioxide aggregates and an experimental root-end filling material. Iranian Endodontic $J$ 2006;1:101-105.

25. Asgary S, Eghbal MJ, Parirokh M, Ghanavati F, Rahimi H. A comparative study of histologic response to different pulp capping materials and a novel endodontic cement. Oral Surg Oral Med Oral Pathol Oral Radiol Endod 2008;106:609614.

26. Kenee DM, Allemang JD, Johnson JD, Hellstein J, Nichol BK. Aquantitative assessment of efficacy of various calcium hydroxide removal techniques. J Endod 2006;32:563565.

27. Ghoddusi J, Asgary S, Parirokh M, Eghbal MJ. Simulated root resorption: A new study model. Iranian Endod $J$ 2008;2:152-155

28. Weisenseel JA, Hicks ML, Pelleu GB. Calcium hydroxide as an apical barrier. J Endod 1987;13:1-5.

29. Hachmeister DR, Schindler WG, Walker WA, Thomas DD. The sealing ability and retention characteristics of mineral trioxide aggregate in a model of apexification. $J$ Endod 2002;28:386-390.

30. Sjogren U, Figdor D, Spangberg L. The antimicrobial effect of calcium hydroxide as a short term intra canal dressing. Int Endod J 1991;24:119-125.

31. Hasselgren G, Olsson B, Cvek M. Effects of calcium hydroxide and sodium hypochlorite on the dissolution of necrotic porcine muscle tissue. J Endod 1988;14: 125-127.

32. Ozturk B, Ozer F, Belli S. An in vitro comparison of adhesive systems to seal pulp chamber walls. Int Endod $J$ 2004;37:297-306

33. Gencoglu N, Orucoglu H, Helvacioglu D. Apical leakage of different gutta-percha techniques: Thermafil, JS QuickFill, Soft Core, Microseal, System B and lateral condensation with a computerized fluid filtration meter. Eur J Dent 2007;1:97-103.

34. Porkaew P, Retief DH, Barfield RD, Lacefield WR, Soong SJ. Effects of calcium hydroxide paste as an intracanal medicament on apical seal. J Endod 1990;16:369-374. 